\title{
Clathrosorus, a New Genus of Plasmodiophoraceae.
}

BY

\author{
C. FERDINANDSEN
}

AND

Ö. WINGE.

With Plate XXI.

THE material of the species here described was sent to us from Sorö, Sealand (Denmark), by Mr. H. Gram, consulting horticulturist, in the month of June, I9I8. On roguing bluebells (Campanula rapunculoides) from his garden Mr. Gram observed that the roots of the named weed often showed numerous small swellings, calling in mind to a certain degree the bacterial tumours on the roots of leguminous plants (see Pl. XXI, Fig. I). Some root-swellings sent to us for closer investigation were fixed in Carnoy, and as it proved that we had before us a new and interesting Plasmodiophoracea we made some slides of the material for a more detailed examination. Preparations stained with cyanine-gold-orange showed in their cytological features a pretty close accordance with the other Plasmodiophoraceae. ${ }^{1}$ We have observed the nuclear divisions in the vegetative stage, whereof Figs. 2 and 3 on Pl. XXI give a pair of pictures, as well as in the akaryotic and sporogonic phase ; in the last-named stage we saw both the heterotypic and the homoiotypic division.

The infection falls only on the cortex, whose more peripheric cells nearly all contain a single plurinucleate myxoplasma or a sporosorus; in the direction of the central cylinder the number of uninfested cells increases. Into the strongly distorted central cylinder itself the parasite never comes. The myxoplasma very often is lodging around the nucleus. The cells are scarcely hypertrophied by the invasion, but are stimulated to more frequent divisions; as a rule the myxoplasma, respectively the sporosorus, will not by far fill out the lumen of the invaded cell. It is further characteristic of

1 See, e.g., Maire et Tisson : La cytologie des Plasmodiophoracées et la classe des Phytomyxinae ; Ann. Myc., I909. Blomfield and Schwartz: Observations on the Tumours on Veronica Chamaedrys caused by Sorosphaera veronicae; Ann. Bot., I910. Winge, Ö.: Cytological Studies in the Plasmodiophoraceae; Arkiv för Botanik, I912.

[Annals of Botany, Vol. XXXIV. No. CXXXVI. October, 1920.] 
the parasite that the ripe sorus has the shape of an irregular, rounded or elongated ball with an uneven surface and traversed by larger and smaller cavities. The individual spores are not so solidly connected as, e.g., in Sorosphaera and Sorodiscus, where the spores are conglutinated with a common substance. In contrast to the case in all hitherto known genera of Plasmodiophoraceae the spores have at the full maturity, but first then, a finely punctuate warty membrane.

We have stated that the spores treated with Carnoy are somewhat collapsing, thus becoming flattened or depressed, and as if provided with a collar, while the spores preserved in diluted alcohol do not show this feature. Most of the other Plasmodiophoraceae seem to behave in the same manner.

Below we give a diagnosis of the new organism.

\section{Clathrosorus, gen. nov.}

Spec. typ.: Clathrosorus campanulae, sp. $\mathrm{n}$.

Plasmodiophoracea radicicola, tumefaciens, cellulas corticis solum infestans. Amplificatio cellularum vix ulla. Sporosori in singulis cellulis sporosoro non impletis singuli, rotundati vel oblongi, saepe irregulares, clathrato-canaliculati. Sporae strato communi non conglutinatae, maturae globosae vel subglobosae, flavidulae, episporio subtiliter punctato-verruculoso.

\section{Clathrosorus Campanulae, sp. nov.}

Statu vegetativo myxamoebae paulatim plurinucleatae in singulis cellulis corticis aggressu vix auctis singulae inventae, nucleum cellula hospitalis saepe amplectentes.

Statu fructifero sporosori in singulis cellulis sporosoro non impletis singuli, transverse secti clathrato-canaliculati, desuper visi rotundati vel oblongi, foveolati et hinc circuitu irregulari, circ. 25-50 $\mu$ lati. Sporae globosae nec non late ellipsoideae, siccitate fluidisve fixativis validis colla-• bescentes, sub vitro gregatim flavidae, singulatim hyalino-flavidulae, episporio subtiliter punctato-verruculoso, $4-5 \frac{1}{2} \mu$ diametro.

Ad radices Campanulae rapunculoidis quae aggressu parasitae eodem fere modo ac radices Leguminosarum bacilligerae intumescunt, in horto prope Soras Daniae. (Leg. H. Gram.) 


\section{EXPLANATION OF PLATE XXI.}

Illustrating Messrs. Ferdinandsen and Winge's paper on Clathrosorus, a New Genus of Plasmodiophoraceae.

Fig. I. Appearance of a specimen of Campanula rapunculoides infested by Clalhrosorus campanulae. Nat. size.

Figs. 2 and 3. Young amoebae showing the characteristic nuclear divisions, anaphase and metaphase respectively. $\times \mathrm{I}, 680$.

Fig. 4. Multinucleate amoeba in a host cell. $\times 75^{\circ}$.

Fig. 5. Multinucleate amoeba surrounding a part of plasma and the nucleus of the host cell. $\times 750$.

Fig. 6. Aggregation of spores in a host cell. $\times 570$.

Fig. 7. Section through a spore ball. $\times 700$.

Fig. 8. Section through two mature spores. $\times$ I,680. 


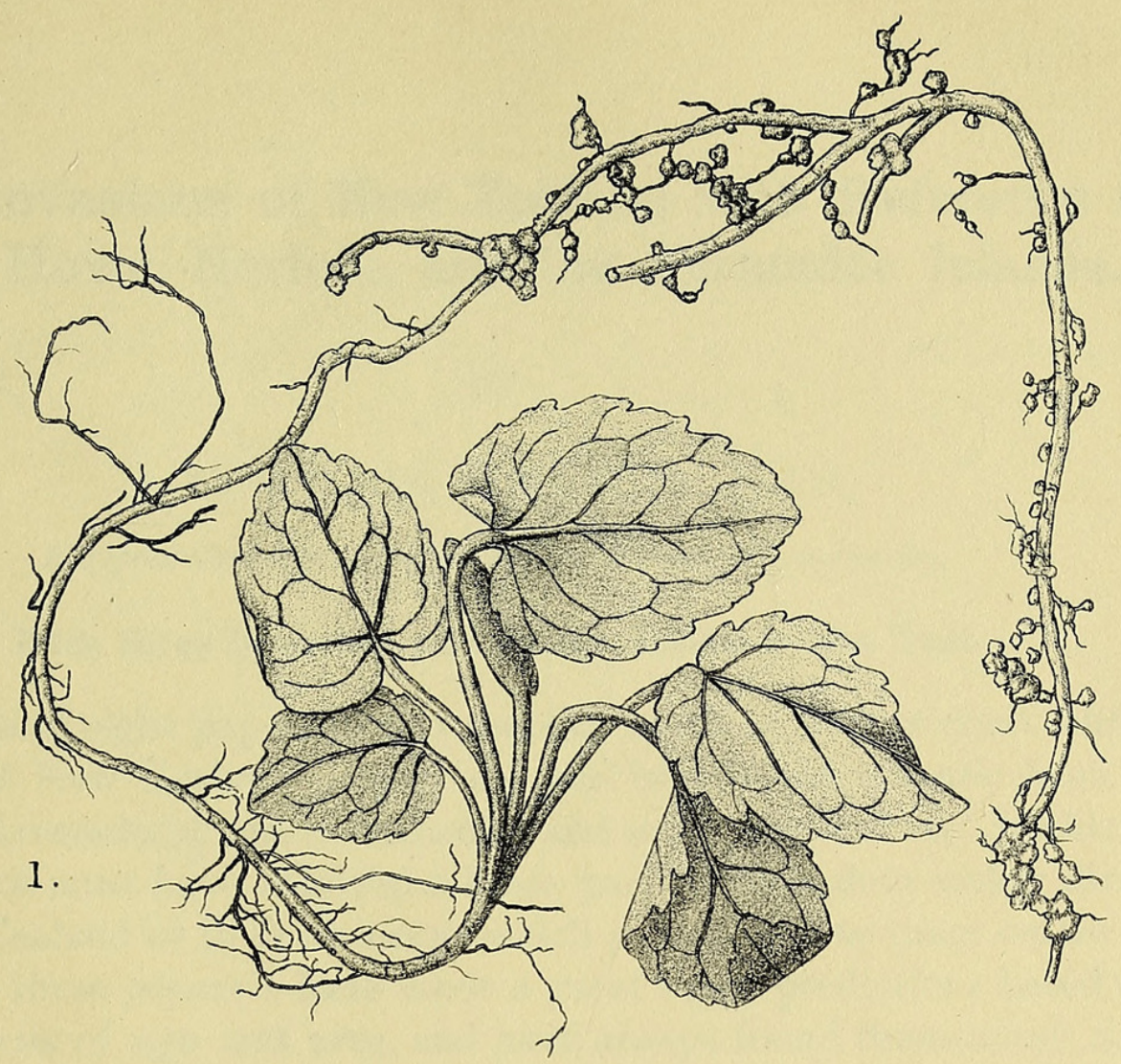

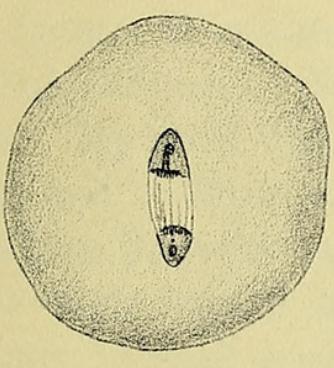

2 .

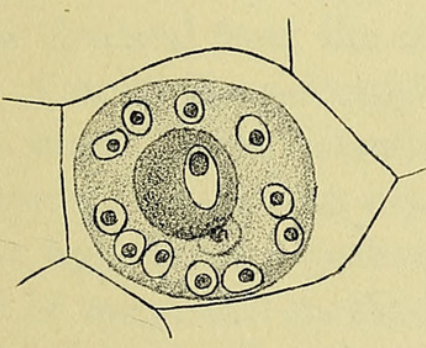

5.

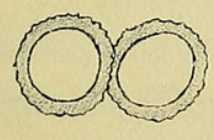

8.

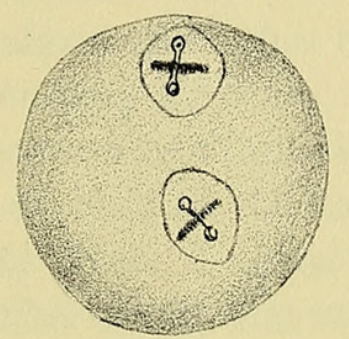

3.

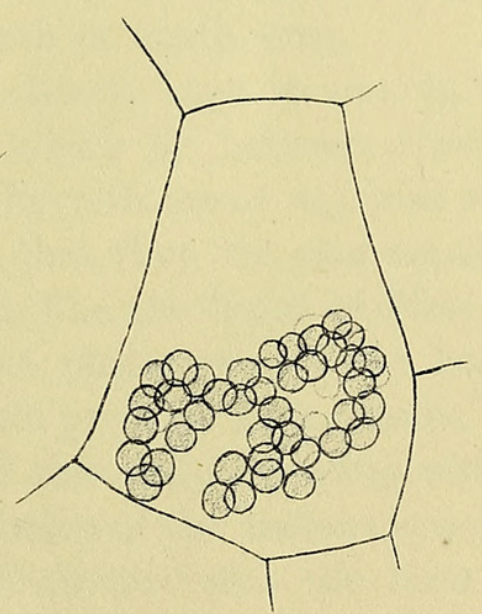

6.

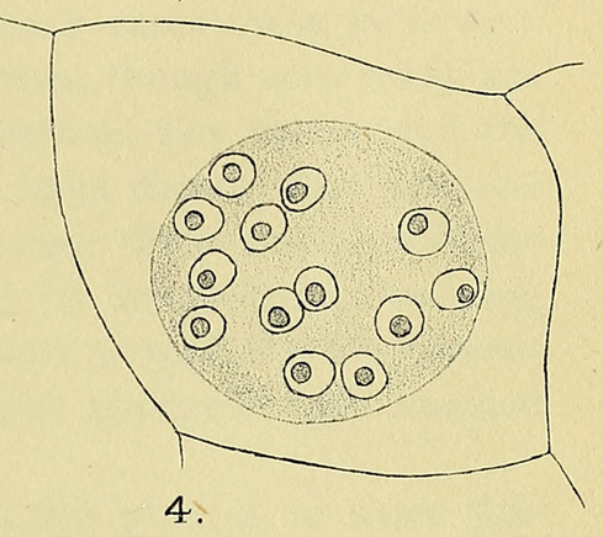

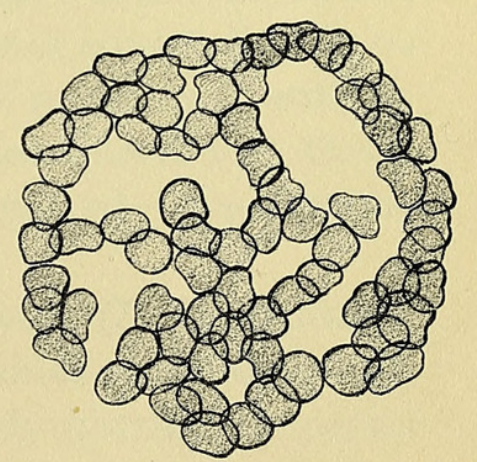

7.

Huth, London.

FERDINANDSEN \& WINGE - CLATHROSORUS. 


\section{$2 \mathrm{BHL}$ Biodiversity Heritage Library}

Ferdinandsen, C. and Winge, Øjvind. 1920. "Clathrosorus, a new genus of Plasmodiophoraceae." Annals of botany 34, 467-469.

https://doi.org/10.1093/aob/os-34.4.467.

View This Item Online: https://www.biodiversitylibrary.org/item/236972

DOI: https://doi.org/10.1093/aob/os-34.4.467

Permalink: https://www.biodiversitylibrary.org/partpdf/320302

\section{Holding Institution}

Smithsonian Libraries

\section{Sponsored by}

Biodiversity Heritage Library

\section{Copyright \& Reuse}

Copyright Status: Not in copyright. The BHL knows of no copyright restrictions on this item.

This document was created from content at the Biodiversity Heritage Library, the world's largest open access digital library for biodiversity literature and archives. Visit BHL at https://www.biodiversitylibrary.org. 